\section{La Révolution française}

Cahiers de l'Institut d'histoire de la Révolution française

5 | 2013

Le républicanisme anglais dans la France des

Lumières et de la Révolution

\title{
Du nouveau dans la recherche historique : Robespierre était un homme, un vrai !
}

\section{Pierre Serna}

\section{OpenEdition}

Journals

Édition électronique

URL : http://journals.openedition.org/lrf/1020

DOI : $10.4000 /$ Irf. 1020

ISSN : 2105-2557

Éditeur

IHMC - Institut d'histoire moderne et contemporaine (UMR 8066)

Référence électronique

Pierre Serna, «Du nouveau dans la recherche historique : Robespierre était un homme, un vrai ! », La Révolution française [En ligne], 5 | 2013, mis en ligne le 31 décembre 2013, consulté le 21 avril 2019. URL : http://journals.openedition.org//rf/1020 ; DOI : 10.4000/Irf.1020

Ce document a été généré automatiquement le 21 avril 2019

(c) La Révolution française 


\section{Du nouveau dans la recherche historique : Robespierre était un homme, un vrai !}

Pierre Serna

\section{NOTE DE L'ÉDITEUR}

Suite à une décision du Comité de lecture de la revue, cet article a été retiré de ce numéro.

\section{AUTEUR}

PIERRE SERNA

Professeur à l'université de Paris I, directeur de l'Institut d'Histoire de la révolution française 